\title{
DETEKSI BAKTERI PATOGEN TERBAWA BENIH AKOR (ACACIA AURICULIFORMIS A. CUNN. EX BENTH.)
}

\author{
Tati Suharti', Tri Joko², \& Triwidodo Arwiyanto ${ }^{2}$ \\ ${ }^{1}$ Program Studi Fitopatologi Program Pascasarjana Universitas Gadjah Mada \\ ${ }^{2}$ Departemen Hama dan Penyakit Tumbuhan, Fakultas Pertanian, Universitas Gadjah Mada \\ Bulaksumur, Yogyakarta 55281 \\ E-mail: tie_772001@yahoo.com
}

\begin{abstract}
Detection of seed-borne pathogenic bacteria of northern black wattle (Acacia auriculiformis A. Cunn. ex Benth.). Intensive research of seed-borne pathogen of A. mangium and A. crassicarpa which have been established in industrial timber estate (HTI), while plantings development of northern black wattle in Indonesia 1990 have not recent been established in the 1990s. Very limited information available on northern black wattle diseases especially seed-borne diseases. The objectives of this study were to identify seed-borne pathogenic bacteria of northern black wattle and the effects on seed germination. Methods for the isolation of bacteria were by seed soaking, seed griding, blotter test, growing-on test on paper and soil. Identification of bacteria by PCR used 63F/1387R primer. The results showed that seed-borne bacteria of northern black wattle were Paenochrobactrum sp., Ralstonia sp., Burkholderia cepacia complex, Pseudomonas stutzeri, Acinetobacter sp., Alcaligenes faecalis, Salmonella bongori, Escherichia hermannii while pathogenic bacteria cause seedling leafspot were Micrococcus luteus and Burkholderia cepacia complex. Burkholderia cepacia complex, A. faecalis, Acinetobater sp., P. stutzeri, S. bongori and Ralstonia sp. reduced seed germination and increased rotten seed, suggested that they were the pathogenic bacteria of northern black wattle seed. Ralstonia sp. significantly increased the percentage of rotten seed and decreased shoot length and root length. P. stutzeri and S. bongori significantly inhibited the root growth. Paenochrobactrum sp. and E. hermannii were assumed as pathogen with weak virulence due to seed germination, the percentage of rotten seed and vigour index were relatively similar to untreated seed.
\end{abstract}

Key words: Acacia auriculiformis, bacteria, pathogen, seed

\begin{abstract}
ABSTRAK
Deteksi bakteri patogen terbawa benih akor (Acacia auriculiformis A. Cunn. ex Benth.). Penelitian patogen terbawa benih sudah banyak dilakukan untuk mangium (A. mangium) dan krasikarpa (A. crassicarpa) yang banyak dikembangkan di HTI namun untuk pengembangan tanaman akor (Acacia auriculiformis) di Indonesia baru dimulai tahun 1990-an sehingga belum banyak informasi mengenai penyakit pada akor di Indonesia khususnya penyakit terbawa benih. Tujuan penelitian ini adalah untuk mengetahui bakteri patogen terbawa benih akor dan pengaruhnya terhadap perkecambahan benih. Isolasi bakteri dilakukan dengan perendaman benih, penggerusan benih, inkubasi benih, growing on test pada kertas dan pada tanah steril. Identifikasi bakteri dengan PCR dengan menggunakan primer 63 F/1378R. Hasil identifikasi menunjukkan bahwa bakteri terbawa benih akor antara lain Paenochrobactrum sp., Ralstonia sp., Burkholderia cepacia complex, Pseudomonas stutzeri, Acinetobacter sp., Alcaligenes faecalis, Salmonella bongori, Escherichia hermannii sedangkan patogen penyebab bercak pada daun bibit akor adalah Micrococcus luteus dan Burkholderia cepacia complex. Burkholderia cepacia complex, A. faecalis, Acinetobater sp., P. stutzeri, S. bongori dan Ralstonia sp. dapat menurunkan daya berkecambah dan meningkatkan persentase benih berlendir sehingga bakteri tersebut diduga merupakan patogen pada benih akor. Ralstonia sp. meningkatkan persentase benih berlendir dan menurunkan panjang tunas dan panjang akar $P$. stutzeri dan $S$. bongori berpengaruh nyata dalam menghambat pertumbuhan akar. Paenochrobactrum sp. dan E. hermannii diduga merupakan patogen dengan virulensi lemah karena daya berkecambah, persentase infeksi benih terinfeksi dan index vigor benih yang diinokulasi $E$. hermannii dan Paenochrobactrum sp. relatif sama dengan pada kontrol.
\end{abstract}

Kata kunci: Acacia auriculiformis, bakteri, benih, patogen 


\section{PENDAHULUAN}

Akor (Acacia auriculifomis) merupakan jenis tanaman hutan yang cepat tumbuh (fast growing species). Akor mempunyai banyak manfaat antara lain untuk industri mebel, bahan baku kertas, konstruksi ringan, sumber tanin, penghijauan, rehabilitasi lahan kritis dan bekas tambang, pemecah angin, pencegah erosi, bahan bakar, peneduh jalan, agroforestri, penghasil madu, substrat jamur edible, industri batik dan keperluan estetik (Turnbull et al., 1998; Joker, 2001).

Dewasa ini akor banyak dikembangkan di hutan tanaman industri (HTI) dan hutan rakyat mengingat salah satu potensi dari tanaman ini sebagai sumber energi. Produktivitas kayu akor $12-15 \mathrm{~m}^{3} / \mathrm{ha} /$ tahun dengan rotasi 10-12 tahun sedangkan produksi arang dari akor mencapai 16 ton/ha/tahun (Gosling, 2007). Akor untuk kebutuhan sumber energi dapat dipanen pada umur 3 tahun (Haishui \& Zengiiang, 1993). Produksi kayu akor di Indonesia mencapai $15-20 \mathrm{~m}^{3} / \mathrm{ha} /$ tahun dengan rotasi 10-12 tahun (Das, 1986 dalam Islam, 2013).

Dalam mendukung program penanaman akor untuk berbagai peruntukan tersebut diperlukan benih bermutu. Namun salah satu kendala dalam pelaksanaan penanaman yaitu tidak tersedianya benih bermutu baik mutu fisik, fisiologis, genetik maupun patologis dalam jumlah yang cukup.

Patogen terbawa benih dapat menyebabkan kerugian secara ekonomi. Kerugian akibat patogen terbawa benih dapat terjadi baik pada saat di lapangan maupun ditempat penyimpanan. Kerugian tersebut dapat terjadi secara langsung pada tanaman yang berasal dari benih yang bersangkutan seperti menurunkan kualitas benih, mengurangi perkecambahan benih, vigor bibit dan daya simpan benih atau dapat terjadi dalam jangka panjang setelah patogen mampu bertahan di tanah, sisa tanaman dan gulma.

Penelitian patogen terbawa benih sudah banyak dilakukan pada mangium (A. mangium) dan krasikarpa (A.crassicarpa) yang banyak dikembangkan di HTI namun untuk pengembangan tanaman akor di Indonesia baru dimulai tahun 1990-an (Hendrati et al., 2014) sehingga belum banyak informasi mengenai penyakit pada akor di Indonesia khususnya penyakit terbawa benih. Penelitian jamur patogen terbawa benih akor sudah dilakukan pada penelitian sebelumnya sedangkan informasi bakteri patogen terbawa benih akor belum banyak dijumpai. Oleh karena itu, penelitian ini dilakukan dengan tujuan mengetahui bakteri patogen terbawa benih akor dan pengaruhnya terhadap perkecambahan benih.

\section{METODE PENELITIAN}

Tempat dan Waktu. Lokasi pengunduhan benih akor (Acacia auriculiformis) yaitu di Desa Banaran, Kecamatan Playen, Kabupaten Gunung Kidul, Yogyakarta. Penelitian dilakukan di Laboratorium Bakteriologi Tumbuhan, Departemen Hama dan Penyakit Tumbuhan, Fakultas Pertanian, Universitas Gadjah Mada dari bulan Juli 2015 sampai Juni 2016.

Isolasi Bakteri dengan Perendaman dan Penggerusan Benih. Benih didisinfeksi dengan natrium hipoklorit $0,5 \%$ selama 4 menit selanjutnya dicuci dengan air suling steril sebanyak 3 kali (Umesha, 2006). Ekstraksi benih menurut Bolkan et al. (1997) yaitu 400 benih dimasukkan ke dalam erlenmeyer yang berisi 50 $\mathrm{ml}$ buffer fosfat $\left(7,75 \mathrm{~g} / \mathrm{l}\right.$ of $\left.\mathrm{K}_{2} \mathrm{HPO}_{4}+1,65 \mathrm{~g} / 1 \mathrm{KH}_{2} \mathrm{PO} 4\right)$ pH7,4 selanjutnya digojok selama 15 menit. Pengenceran berseri sampai $10^{-5}$ dilakukan dengan buffer fosfat. Sebanyak $0,1 \mathrm{ml}$ dari masing-masing pengenceran ditumbuhkan pada media YPA (pepton $10 \mathrm{~g}$, yeast $3 \mathrm{~g}$, akuades $1000 \mathrm{ml}$ ) (Schaad et al., 2001) dan King's B (pepton $20 \mathrm{~g}, \mathrm{KH}_{2} \mathrm{PO} 41,5 \mathrm{~g}, \mathrm{MgSO}_{4} .7 \mathrm{H}_{2} \mathrm{O} 1,5 \mathrm{~g}$, gliserol $15 \mathrm{ml}$, agar $5 \mathrm{~g}$, akuades $1000 \mathrm{ml}$ ) (Schaad et al., 2001) yang ditambahkan 100 ppm Cycloheximide. Untuk penggerusan, benih setelah disterilisasi digerus dengan menggunakan mortar selanjutnya digojok selama 15 menit dan dilakukan pengenceran berseri.

Metode Inkubasi dengan Media Kertas. Benih sebanyak 400 (100 x 4 ulangan) diletakkan di dalam cawan petri berdiameter $15 \mathrm{~cm}$ yang telah diberi tiga lapis kertas saring basah. Sebelum dikecambahkan, terdapat 2 perlakuan terhadap benih yang disterilisasi terlebih dahulu dengan $\mathrm{NaOCl} 0,5 \%$ kemudian dicuci air steril sebanyak 3 kali dan benih yang tidak disterilisasi (hanya dicuci air steril). Selanjutnya benih diinkubasi pada suhu kamar dengan penyinaran lampu 12 jam terang dan 12 jam gelap secara bergantian selama 7 hari. Pengamatan meliputi identifikasi bakteri patogen, gejala penyakit pada benih dan persentase infeksi bakteri.

Growing-on Test pada Media Kertas. Benih sebanyak 400 (100 x 4 ulangan) direndam dalam air panas (suhu $\pm 97^{\circ} \mathrm{C}$ ) dan dibiarkan sampai dingin selama 24 jam selanjutnya ditabur pada media kertas steril. Pengamatan dilakukan selama 4 minggu, meliputi daya berkecambah dan persentase benih terinfeksi bakteri. 
Growing-on Test pada Media Tanah Steril. Uji ini ditujukan untuk meniru atau mewakili kondisi lapangan. Pengujian ini dilakukan untuk bakteri patogen terbawa benih yang membutuhkan waktu inkubasi lama sehingga menghasilkan gejala pada bibit. Benih ditabur sebanyak 400 butir (100 x 4 ulangan) pada nampan berisi tanah steril. Polybag $(20 \times 10 \mathrm{~cm})$ diisi tanah steril sebanyak $3 / 4$ volume polybag selanjutnya bibit yang berumur 1 bulan dipindah ke polybag sebanyak 1 bibit/polybag. Pengamatan dilakukan sampai bibit berumur 3 bulan. Apabila terdapat penyakit yang disebabkan bakteri, patogen diisolasi dan selanjutnya diidentifikasi.

Uji Reaksi Hipersensitif (HR). Suspensi bakteri dibuat dengan air steril dengan kepadatan $\pm 10^{8} \mathrm{sel} / \mathrm{ml}$. Suspensi bakteri diinfiltrasikan ke dalam helai daun tembakau dengan alat injeksi yang jarumnya dilepas sampai nampak bercak kebasahan (hijau tua). Kontrol menggunakan air steril. Pengamatan dilakukan sampai tujuh hari kemudian.

Uji Inokulasi Buatan pada Tanaman Inang. Bibit akor diinokulasi dengan suspensi bakteri yang menunjukkan gejala klorosis atau nekrosis pada uji HR. Gunting dicelupkan dalam suspensi bakteri dengan kepadatan $\pm 10^{8} \mathrm{sel} / \mathrm{ml}$. Selanjutnya daun diinokulasi dengan suspensi bakteri dengan cara menggunting daun sebanyak 4 ulangan untuk masing-masing isolat. Kontrol menggunakan air steril.

Uji Reaksi Gram. Isolat yang menunjukkan gejala pada uji patogenesitas kemudian dilakukan uji Gram. Pengujian dengan menggunakan $\mathrm{KOH} 3 \%$. Satu ose bakteri diletakkan pada gelas benda dan diberi satu tetes KOH 3\% lalu dicampur-ratakan. Apabila ketika jarum ose diangkat terbentuk benang lendir maka bakteri merupakan Gram negatif.

Uji Oksidasi Fermentasi (OF). Satu ose bakteri ditusukkan ke dalam tabung reaksi yang berisi media $\mathrm{OF}$ (pepton 2,0 g, NaCl 5,0 g, glukosa 10,0 g, $\mathrm{KH}_{2} \mathrm{PO}_{4}$ 0,3 g, agar $15 \mathrm{~g}$, bromtymol blue (1\%) 3,0 ml, aquades 1000 ml, PH 6,8 -7,1 (Sands, 1990). Media diberi minyak parafin dan tidak diberi minyak parafin masing-masing sebanyak 3 tabung. Selanjutnya semua tabung tersebut diinkubasi pada suhu kamar dan diamati selama 2 minggu. Apabila terjadi perubahan warna hijau menjadi kuning pada tabung yang diberi dan tidak diberi minyak parafin, maka bakteri tersebut aerob/anaerob fakultatif.

Uji Oksidase. Satu ose bakteri digoreskan pada kertas filter yang telah mengandung tetramethil- parafenilendiamin dihidroklorida $(\mathrm{C} 6 \mathrm{H} 4[\mathrm{~N}(\mathrm{CH} 3) 2]$ $2 \cdot 2 \mathrm{HCl}) 1 \%$. Apabila terjadi perubahan warna menjadi merah keunguan dalam waktu 10-60 detik, maka bakteri mempunyai sitokrom $\mathrm{C}$.

Uji Katalase. Satu ose bakteri diletakkan pada gelas benda. Selanjutnya diberi satu tetes $\left(\mathrm{H}_{2} \mathrm{O}_{2}\right)$. Apabila terbentuk gelembung udara maka bakteri mempunyai enzim katalase.

PCR. Isolat bakteri yang akan diidentifikasi dengan PCR adalah isolat yang menunjukkan gejala klorosis atau nekrosis pada uji HR dan uji inokulasi buatan pada tanaman inang dari setiap metode (perendaman benih, penggerusan benih, inkubasi pada kertas, growing-on test pada kertas dan tanah steril). Apabila dari masingmasing metode tersebut menghasilkan warna koloni yang berbeda maka koloni yang berbeda warna tersebut diidentifikasi dengan PCR. Primer yang digunakan yaitu primer universal 63F (5 - CAG GCC TAA CAC ATG CAA GTC-3) dan 1378R (5 -GGG CGG WGT GTA CAA GGC - 3) (Marchesi et al., 1998). Pasangan primer $63 \mathrm{~F} / 1378 \mathrm{R}$ memiliki urutan basa 1300 pasang basa. Marker yang dipakai adalah 1 kilo pasang basa. Tahapan identifikasi dengan PCR yaitu isolasi DNA bakteri, amplifikasi DNA dengan PCR dan elektroforesis.

Isolasi DNA bakteri. Isolasi DNA mengikuti metode yang dikembangkan Ausubel et al. (2003) dengan modifikasi (Berlian, 2012).

Amplifikasi DNA dengan PCR. Mesin PCR yang digunakan yaitu MJ Research PTC-150 MiniCycler, BIO RAD. Komposisi yang digunakan sebanyak $25 \mu$ l yang terdiri dari $12,5 \mu \mathrm{l}$ kapa taq ready mix, $1 \mu 1$ primer F 10 pmol, $1 \mu 1$ primer $\mathrm{R} 10$ pmol, aquabides $9,5 \mu 1$ dan DNA bakteri $1 \mu$ l. Siklus amplifikasi yang digunakan yaitu predenaturasi dengan suhu $95^{\circ} \mathrm{C}$ selama 3 menit, denaturasi dengan suhu $95{ }^{\circ} \mathrm{C}$ selama 30 detik, annealing dengan suhu $50^{\circ} \mathrm{C}$ selama 30 detik, ekstension dengan suhu $72{ }^{\circ} \mathrm{C}$ selama 1 menit dengan final ekstension dengan suhu $72{ }^{\circ} \mathrm{C}$ selama 2 menit sebanyak 35 siklus.

Elektroforesis. Visualisasi DNA menggunakan agarose $1 \%$. Agarose ditimbang sebanyak $0,3 \mathrm{~g}$ dan dimasukkan ke dalam botol kaca selanjutnya ditambah TBE $1 \mathrm{X}$ sebanyak $30 \mathrm{ml}$. Setelah itu dipanaskan dengan menggunakan microwave selama \pm 5 menit. Larutan dituang ke dalam cetakan (gel tray). DNA hasil amplifikasi dimasukkan ke dalam sumuran gel masingmasing sebanyak $3 \mu \mathrm{l}$. DNA marker yang digunakan adalah 1 kilo pasang basa sebanyak $3 \mu \mathrm{l}$. Gel agarosa 
dimasukkan ke dalam mesin elektroforesis yang berisi TBE $1 \mathrm{X}$. Elektroforesis dilakukan selama 45 menit pada 50 volt. Setelah itu dilakukan pewarnaan dengan menggunakan ethidium bromide (EtBR) dengan merendam gel selama 10 menit selanjutnya visualisasi DNA dengan menggunakan UV transiluminator (UV Transiluminator 2000, BIO RAD).

Analisis Sekuen DNA dan Filogenetik. DNA hasil amplifikasi selanjutnya disekuensing yang dilakukan oleh PT. Genetika Science Indonesia dengan menggunakan pasangan primer $63 \mathrm{~F} / 1387 \mathrm{R}$. Analisis homologi hasil sekuensing menggunakan program Blast (Basic Local Alignment Search Tool) di NCBI. Analisis sekuen nukelotida isolat dan filogenetik menggunakan software MEGA 6 (Tamura et al., 2013) berdasarkan pendekatan Neighbor- Joining (NJ).

\section{HASIL DAN PEMBAHASAN}

Gejala Benih Akor Diduga Terinfeksi Bakteri pada Perkecambahan di Media Kertas. Benih yang diduga terinfeksi bakteri ditandai dengan adanya lendir pada permukaan benih. Benih yang berlendir tersebut secara umum tidak dapat berkecambah. Gejala lain benih yang diduga terinfeksi bakteri yaitu dengan ditandai benih berlendir, hampa dan busuk (Gambar 1). Pada bibit umur 2 bulan ditemukan bibit yang diduga terinfeksi patogen dengan ditandai bercak coklat yang dimulai dari ujung daun (Gambar 1c).

Lendir yang terdapat di permukaan benih diamati dengan menggunakan TEM (transmission electron microscope). Lendir pada permukaan benih akor di perkecambahan diduga terdapat populasi berbagai jenis bakteri dengan bermacam-macam bentuk seperti batang, batang bengkok, batang bulat (Gambar 2).

Identifikasi Bakteri Patogen Terbawa Benih Akor. Pada metode penggerusan benih dan diisolasi pada media Kings'B tidak ditemukan koloni bakteri setelah diinkubasi selama seminggu. Jumlah isolat bakteri dan persentase isolat yang menunjukkan gejala klorosis dan nekrosis pada uji hipersensif dan uji inokulasi buatan pada tanaman inang dari masing-masing metode tertera pada Tabel 1.

Gejala klorosis dan nekrosis pada uji HR yang paling banyak ditemukan pada isolat dari inkubasi benih baik yang disterilisasi dengan $\mathrm{NaOCl}$ maupun yang tidak disterilisasi dan isolat dari daun bibit (growing on test)
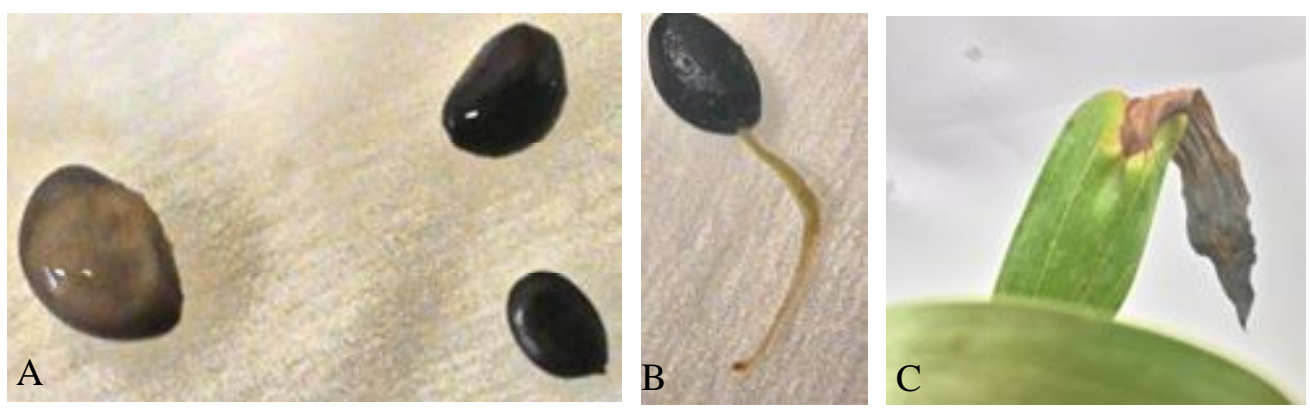

Gambar 1. Beberapa gejala penyakit yang diduga disebabkan bakteri pada benih, kecambah dan daun bibit; A. Benih berlendir dan benih sehat, B. Kecambah busuk, C. Bercak coklat
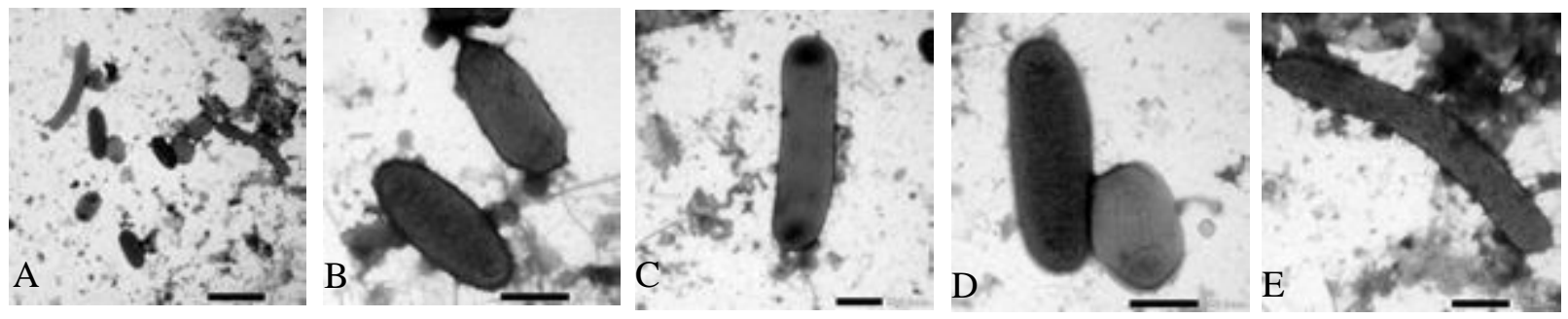

Gambar 2. Morfologi sel bakteri terbawa benih akor; A. Morfologi beberapa jenis bakteri yang terdapat pada permukaan benih akor di Perkecambahan, B. Sel bakteri berbentuk batang oval (ovoid bacillus) dengan flagel, C. Sel bakteri berbentuk panjang dengan flagel, D. Sel bakteri berbentuk panjang (bacillus) tidak berflagel dan berbentuk batang bulat (coccusbacillus), E. Sel bakteri berbentuk panjang membengkok (curve bacillus) 
sedangkan yang paling sedikit menghasilkan gejala diperoleh dari penggerusan benih (47\%). Gejala dimulai dengan klorosis tetapi apabila berkembang dengan cepat dapat menghasilkan gejala nekrosis (Gambar 3). Umumnya gejala klorosis dan nekrosis jelas terlihat pada 48 jam setelah inokulasi. Fanani et al. (2015) melaporkan bahwa pada uji HR, bakteri patogen pada tanaman kantong semar menunjukkan gejala nekrosis dalam waktu 48 jam setelah inokulasi.

Gejala klorosis dan nekrosis pada uji inokulasi buatan muncul mulai hari ke-4. Hadianto et al. (2015) melaporkan bahwa uji inokulasi buatan Xanthomonas oryzae pv. Oryzae pada padi varietas Inpari menghasilkan gejala nekrosis pada hari ke-4. Gejala yang ditimbulkan yaitu bercak nekrotik berwarna coklat di sekitar tempat inokulasi atau klorosis di jaringan sekitar tempat inokulasi (Gambar 4). Isolat yang diperoleh dari benih (bukan dari bibit) menghasilkan gejala klorosis dan nekrosis pada uji inokulasi buatan yang sama dengan pada uji HR yaitu paling sedikit ditemukan pada isolat penggerusan benih $(20,75 \%)$ sedangkan yang paling banyak ditemukan pada isolat inkubasi benih yang disterilisasi $\mathrm{NaOCl}$ (70\%). Dengan demikian metode penggerusan benih menghasilkan isolat paling sedikit yang menghasilkan gejala pada uji HR dan uji inokulasi buatan, sebaliknya metode yang menghasilkan isolat yang

Tabel 1. Jumlah isolat bakteri dari berbagai metode yang menunjukkan gejala klorosis dan nekrosis pada uji hipersensitif dan uji inokulasi buatan pada tanaman inang

\begin{tabular}{lcccc}
\hline \multicolumn{1}{c}{ Metode } & Media & Jumlah isolat & $\begin{array}{c}\text { Uji Hipersensitif } \\
(\%)\end{array}$ & $\begin{array}{c}\text { Uji Inokulasi } \\
\text { Buatan (\%) }\end{array}$ \\
\hline Perendaman & KB & 21 & 66,67 & 45,00 \\
Perendaman & YPA & 42 & 57,14 & 26,19 \\
Penggerusan & KB & - & - & - \\
Penggerusan & YPA & 53 & 47,00 & 20,75 \\
Inkubasi pada kertas disterilisasi NaOCl & YPA & 10 & 100,00 & 70,00 \\
Inkubasi pada kertas tidak disterilisasi NaOCl & YPA & 18 & 100,00 & 44,44 \\
Growing on test pada kertas & YPA & 10 & 60,00 & 50,00 \\
Growing on test pada tanah steril & YPA & 10 & 100,00 & 30,00 \\
\hline
\end{tabular}

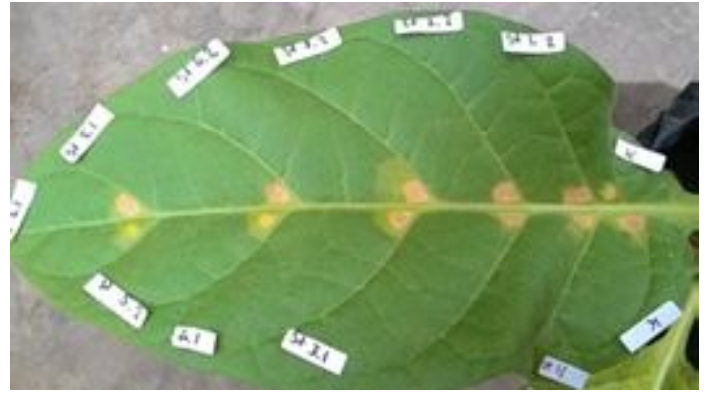

Gambar 3.Gejala klorosis dan nekrosis pada uji HR
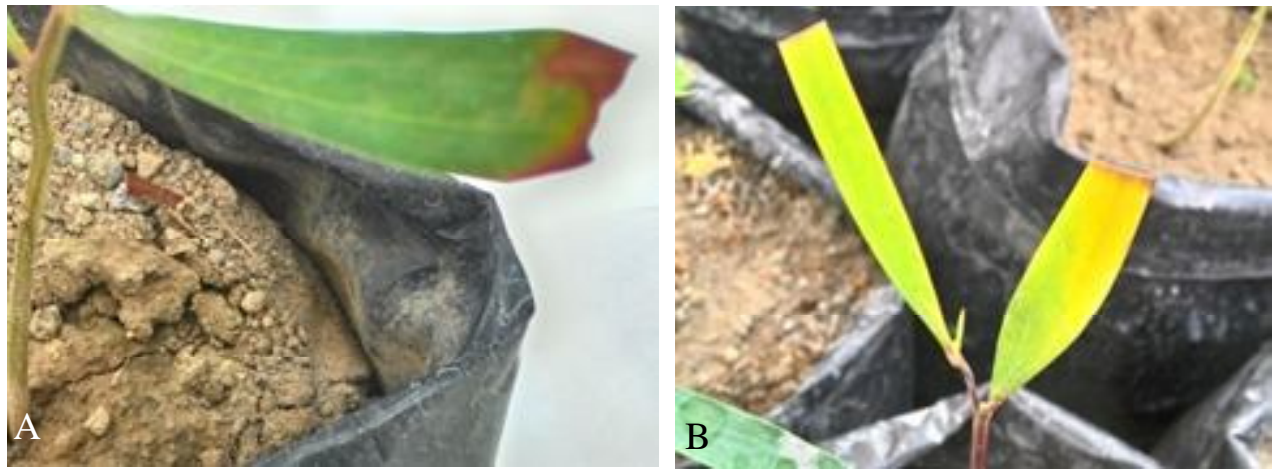

Gambar 4. Gejala pada uji inokulasi buatan; A. Nekrosis, B. Klorosis 
relatif banyak menghasilkan gejala pada uji HR dan uji inokulasi buatan adalah metode inkubasi benih yang disterilisasi $\mathrm{NaOCl}$.

Isolat yang menunjukkan gejala klorosis dan nekrosis pada uji inokulasi buatan selanjutnya dilakukan uji Gram, katalase, oksidase dan oksidasi fermentasi sebanyak 40 isolat. Hampir semua isolat yang diuji merupakan bakteri Gram negatif. Terdapat satu isolat (B2) merupakan bakteri Gram positif. Semua isolat yang diuji merupakan bakteri aerob dan mempunyai enzim katalase (Tabel 2).

Tabel 2. Beberapa karakteristik isolat dari masing-masing metode

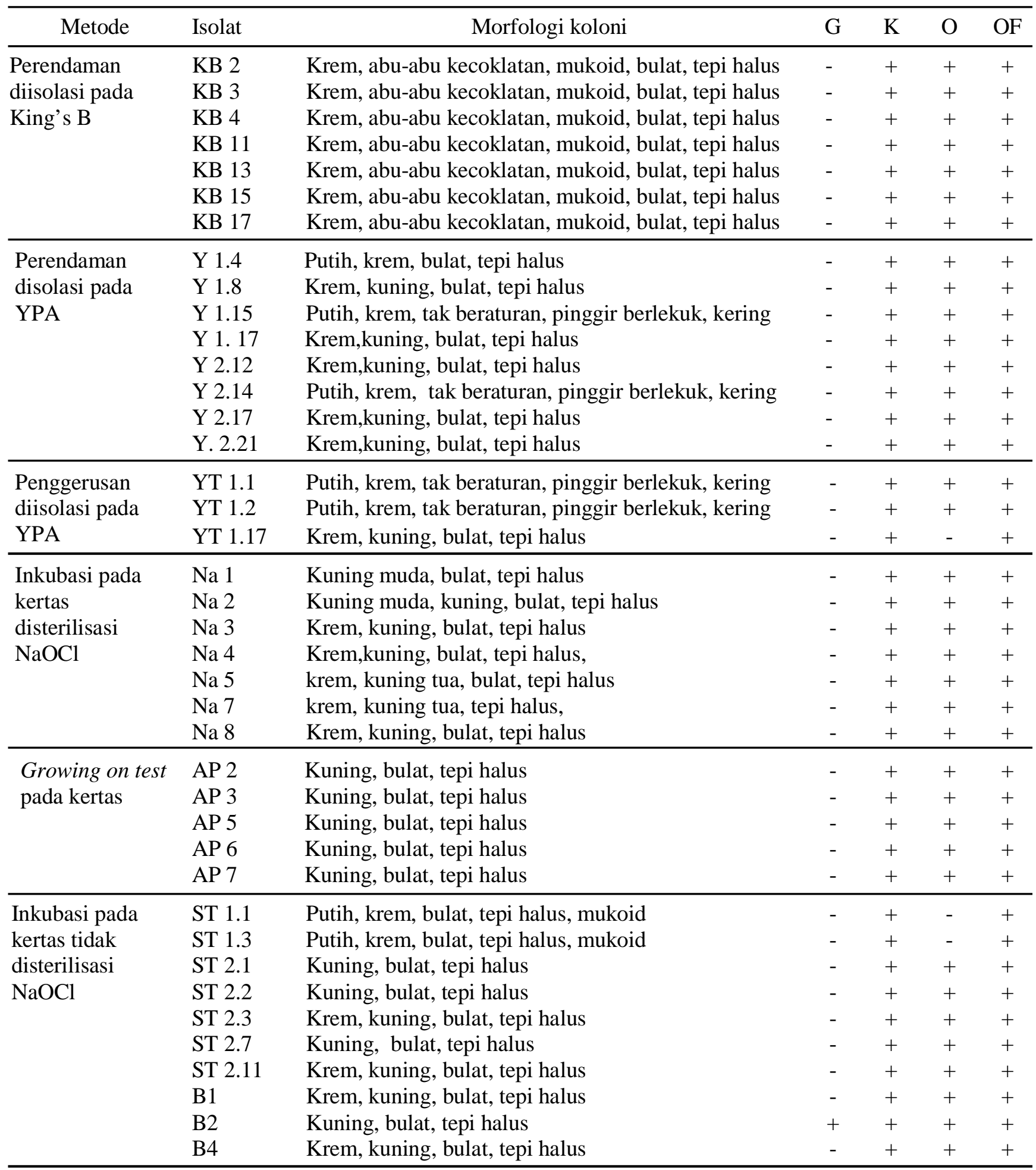

G: Gram; K: Katalase; O: Oksidase; OF: Oksidasi fermentasi 
Hasil pengujian menggunakan metode PCR ditentukan berdasarkan panjang produk DNA yang dihasilkan dari proses PCR. Panjang produk PCR ditentukan dengan mensejajarkan pita DNA target dengan marker yang memiliki skala penanda panjang DNA. Hasil positif ditentukan dari posisi pita DNA yang sesuai dengan panjang produk yang diharapkan. Fragmen DNA hasil amplifikasi masing-masing isolat bakteri teramplifikasi dan diperkirakan mempunyai ukuran \pm 1300 pasang basa (Gambar 5). Keberhasilan amplifikasi
DNA dipengaruhi oleh beberapa faktor, salah satunya yaitu konsentrasi primer. Joko et al. (2011) melaporkan bahwa pengenceran primer 10x (10 pmol) menghasilkan amplifikasi DNA yang optimal.

Hasil analisis sekuensing semua isolat dengan BLAST pada NCBI diperoleh E-value nol sehingga semua sekuen homolog dengan sekuen yang terdapat di NCBI (Tabel 3). Pensejajaran hasil sekuensing dengan sekuen yang terdapat pada GenBank diperoleh tingkat kemiripan $\geq 98 \%$ sebanyak 9 isolat dan terdapat 2 isolat

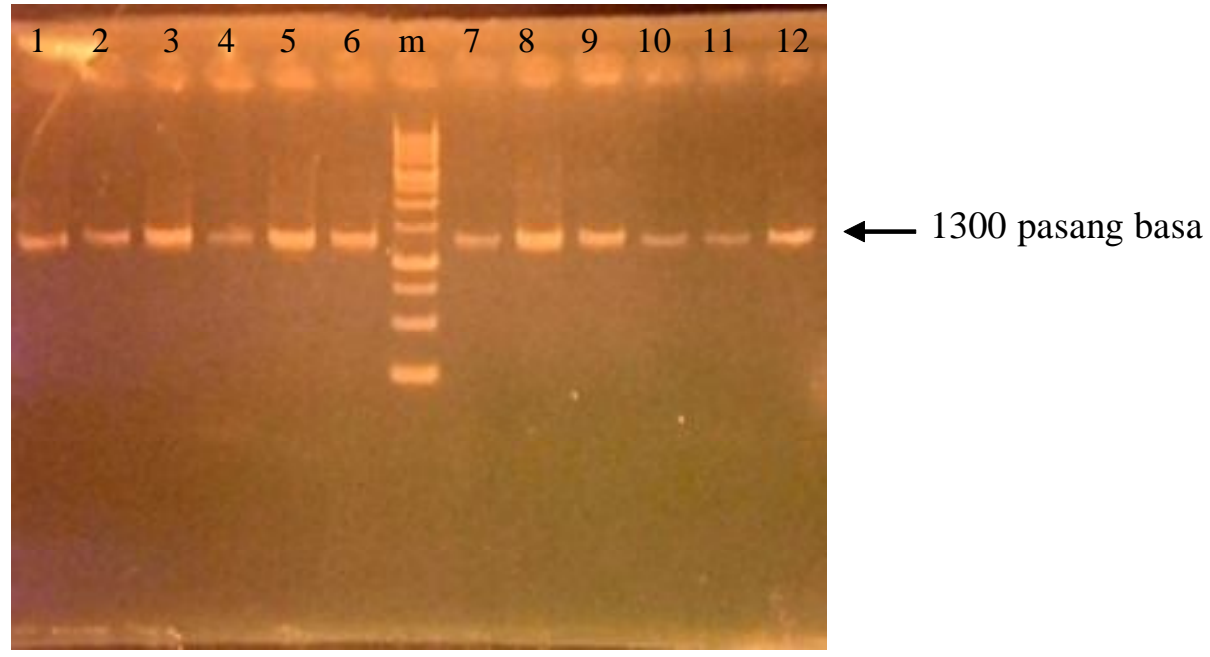

Gambar 5. Hasil elektroforesis gel amplifikasi gen 16S rRNA; 1. isolat AP 3, 2. isolat B1, 3. isolat Na7, 4. isolat YT $1.17,5$. isolat ST 2.2, 6. isolat Y 2.12, 7. isolat $\mathrm{KB} 3,8$. isolat $\mathrm{B} 2,9$. isolat $\mathrm{Na} 1,10$. isolat $\mathrm{YT} 1.2,11$. isolat ST 1.3, 12. isolat Y $2.14, \mathrm{~m}=$ marker

Tabel 3. Hasil pensejajaran sekuen isolat beberapa bakteri pada benih dan bibit akor dengan sekuen yang terdapat pada GenBank

\begin{tabular}{lcccccl}
\hline \multicolumn{1}{c}{ Isolat } & $\begin{array}{c}\text { Max } \\
\text { score }\end{array}$ & $\begin{array}{c}\text { Total } \\
\text { score }\end{array}$ & $\begin{array}{c}\text { Query } \\
\text { cover }\end{array}$ & E-value & Ident & \multicolumn{1}{c}{ Sekerabat } \\
\hline KB 3 & 987 & 987 & $72 \%$ & 0 & $87 \%$ & Paenochrobactrum sp. \\
AP 3 & 2169 & 2169 & $95 \%$ & 0 & $97 \%$ & Ralstonia sp. \\
B1 & 2170 & 2170 & $93 \%$ & 0 & $99 \%$ & Burkholderia cepacia complex \\
B2 & 2226 & 2226 & $97 \%$ & 0 & $98 \%$ & Micrococcus luteus \\
Na1 & 1238 & 1238 & $100 \%$ & 0 & $100 \%$ & Alcaligenes faecalis \\
Na7 & 1271 & 1271 & $85 \%$ & 0 & $88 \%$ & Acinetobacter sp. \\
ST 1.13 & 1136 & 1507 & $99 \%$ & 0 & $99 \%$ & Escherichia hermannii \\
ST 2.2 & 1832 & 2424 & $99 \%$ & 0 & $99 \%$ & Burkholderia cepacia complex \\
YT 1.2 & 1858 & 2482 & $99 \%$ & 0 & $99 \%$ & Pseudomonas stutzeri \\
YT 1.17 & 1875 & 2401 & $99 \%$ & 0 & $99 \%$ & Salmonella bongori \\
Y 2.12 & 1881 & 2406 & $99 \%$ & 0 & $99 \%$ & Burkholderia cepacia complex \\
Y 2.14 & 1149 & 1474 & $99 \%$ & 0 & $99 \%$ & Pseudomonas stutzeri \\
\hline
\end{tabular}


yang mempunyai tingkat kemiripan relatif rendah yaitu AP3 (87 \%) dan Na7 (88 \%). Selanjutnya hubungan kekerabatan untuk tiap isolat divisualisasikan dalam pohon filogenetik.

Hasil pensejajaran sekuen isolat KB3 dengan sekuen pada GenBank sekerabat dengan Paenochrobactrum sp. (Gambar 6) dengan tingkat kemiripan sebesar $87 \%$.

Paenochrobactrum sp. merupakan bakteri endofit pada kilemo (Litsea cubeba) (Ling et al., 2012). Bakteri dari famili yang sama (Brucellaceae) yaitu Ochrobactrum antropi merupakan patogen pada benih Prunus dulcis (Rakhashiya et al., 2016).

Isolat AP3 sekerabat dengan Ralstonia sp. dengan tingkat kemiripan sebesar 97\% (Gambar 7). Ralstonia sp. ditemukan pada benih mentimun (Ofek et al., 2011).

Isolat B1, ST 2.2 dan Y 2.12 sekerabat dengan Burkholderia cepacia complex dengan tingkat kemiripan 99\% (Gambar 8). Dari Gambar 8 terlihat bahwa ketiga isolat belum bisa dipastikan spesiesnya karena Burkholderia cepacia complex memiliki hubungan kekerabatan yang dekat, namun ketiga isolat ini memiliki kekerabatan genetik yang dekat dengan Burkholderia contaminans. Burkholderia cepacia complex terdiri dari 17 spesies antara lain Burkholderia cepacia, B. multivorans, B. cenocepacia, B. stabilis, $B$. vietnamiensis, B. dolosa, B. ambifaria, B. anthina, $B$. pyrrocinia, B. ubonensis, B. latens, $B$. diffusa, $B$. arboris, B. seminalis, B. metallica, $B$. contaminans dan B. lata. Dua spesies terbaru yaitu $B$. contaminans dan B. lata (Vanlaere et al., 2009). Beberapa spesies dilaporkan memiliki hubungan kekerabatan yang dekat seperti Burkholderia cepacia complex (>97,5\%) dengan 16S rRNA (Coenye et al., 2001) sehingga untuk membedakan ketiga isolat tersebut sebaiknya mengunakan primer gen housekeeping. Gen housekeeping merupakan gen fungsional yang mempunyai laju evolusi lebih tinggi daripada gen $16 \mathrm{~S}$ rRNA (Avise, 1994). Mahenthiralingam et al. (2000) melaporkan bahwa gen recA merupakan gen housekeeping yang dapat membedakan keragaman

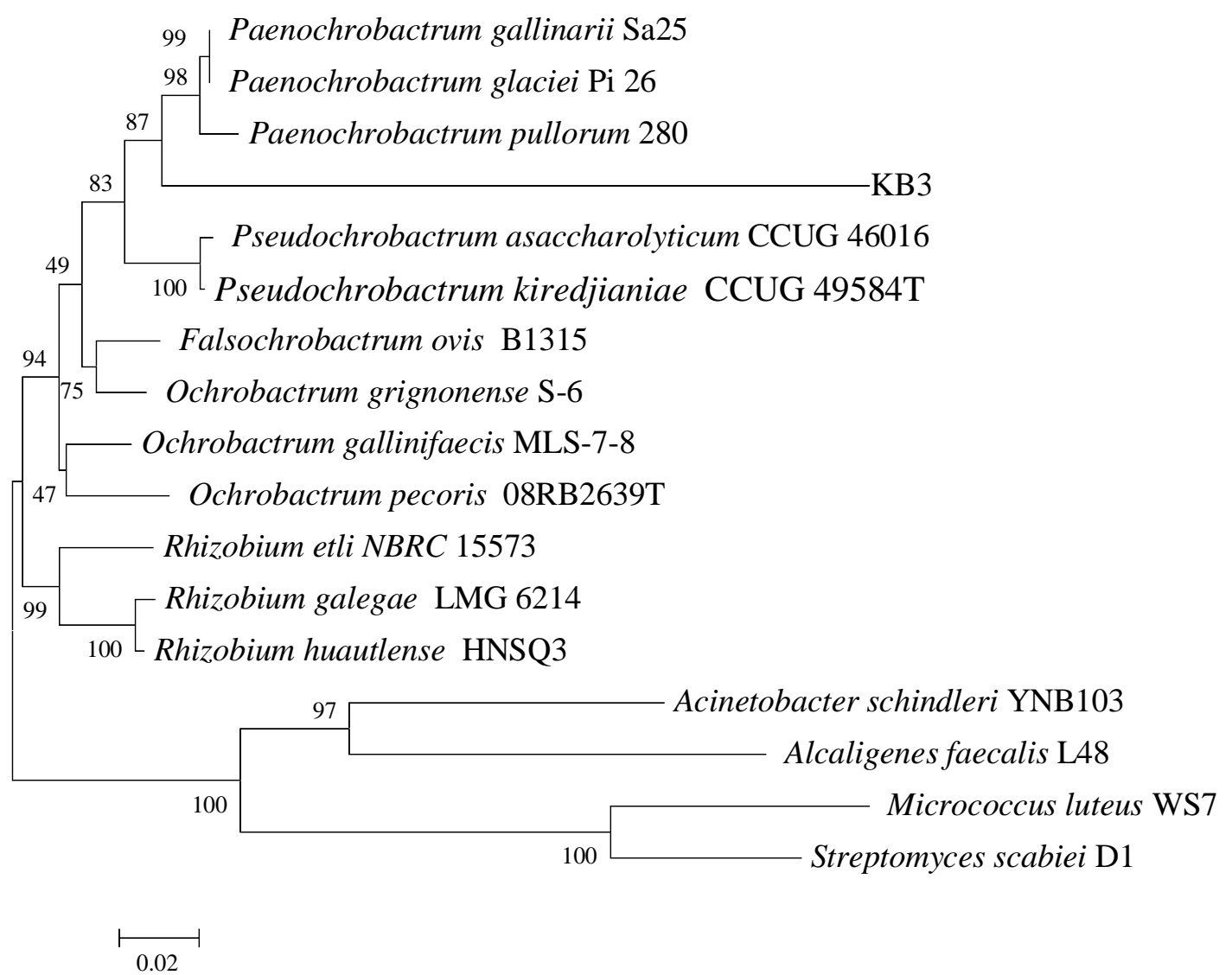

Gambar 6. Pohon filogenetik menunjukkan hubungan kekerabatan antara isolat KB3 berdasarkan sekuen 16S rRNA yang terdapat di GenBank. Rekonstruksi pohon filogenetik menggunakan pendekatan NeighborJoining (NJ) dengan bootstrap 1000x. Sekuen Acinetobacter shindleri, Alcaligenes faecalis, Micrococcus luteus dan Streptomyces scabiei digunakan sebagai outgroup 
Burkholderia cepacia complex. Burkholderia sp. ditemukan pada benih mentimun (Ofek et al., 2011). Burkholderia sp. dapat berada di xylem, substomatal chamber dan bagian aerial tanaman anggur melalui aliran transpirasi (Compant et al., 2005). Burkholderia cepacia complex dilaporkan ditemukan pada akar dan batang tebu (Gonzalez et al., 2011).

Isolat B2 sekerabat dengan Micrococcus luteus dengan tingkat kemiripan 98\% (Gambar 9). Micrococus sp. merupakan patogen pada tanaman horse chestnut (Aesculus L.). Patogen menyebabkan tunas kering dan $1 / 3$ sampai $1 / 2$ permukaan daun nekrosis. Terdapat klorosis di sekitar nekrosis. Nekrosis terdapat pada ujung sampai tengah daun kemudian menjadi kering (Iakovleva et al., 2013). Gejala tersebut sama seperti yang terdapat pada daun bibit akor. Rakhashiya et al. (2015) melaporkan bahwa di India, M. luteus menyebabkan bercak daun mangga. Daun yang terinfeksi dapat gugur sehingga dapat menurunkan produksi buah mangga.

Isolat $\mathrm{Na} 1$ sekerabat dengan Alcaligenes faecalis dengan tingkat kemiripan 100\% (Gambar 10).
Bakteri ini ditemukan pada benih gulma Abutilon theophrasti dan Datura stramonium (Kremer et al., 1987).

Isolat $\mathrm{Na} 7$ sekerabat dengan Acinetobacter sp. dengan tingkat kemiripan 88\% (Gambar 11). Dari beberapa penelitian melaporkan bahwa Acinetobacter sp. dapat menyebabkan kerusakan pada fase benih, kecambah sampai tanaman dewasa pada berbagai jenis tanaman seperti tanaman hortikultur, tanaman pangan dan tanaman keras dan menginfeksi berbagai organ (benih, tangkai bunga, batang, tunas). Bakteri ini ditemukan pada benih gulma Abutilon theophrasti, Datura stramonium (Kremer et al., 1987), Cassia fistula (Kaur et al., 2009) dan mentimun (Ofek et al., 2011). Bakteri ini dapat menyebabkan busuk kecambah kedelai (Yun \& Kim, 2003), layu pada bibit pinus (Pinus thunbergii) (Xie et al., 2004), penyakit pada daun mangrove (Rhizophora mangle) (Ukoima et al., 2009), patah tangkai bunga gerbera (Gerbera jasmonii L.) (Balestra et al., 2005) dan kurma (Phoenix dactilyfera) (Rivas et al., 2007), mati pucuk pada mangga (Khan et

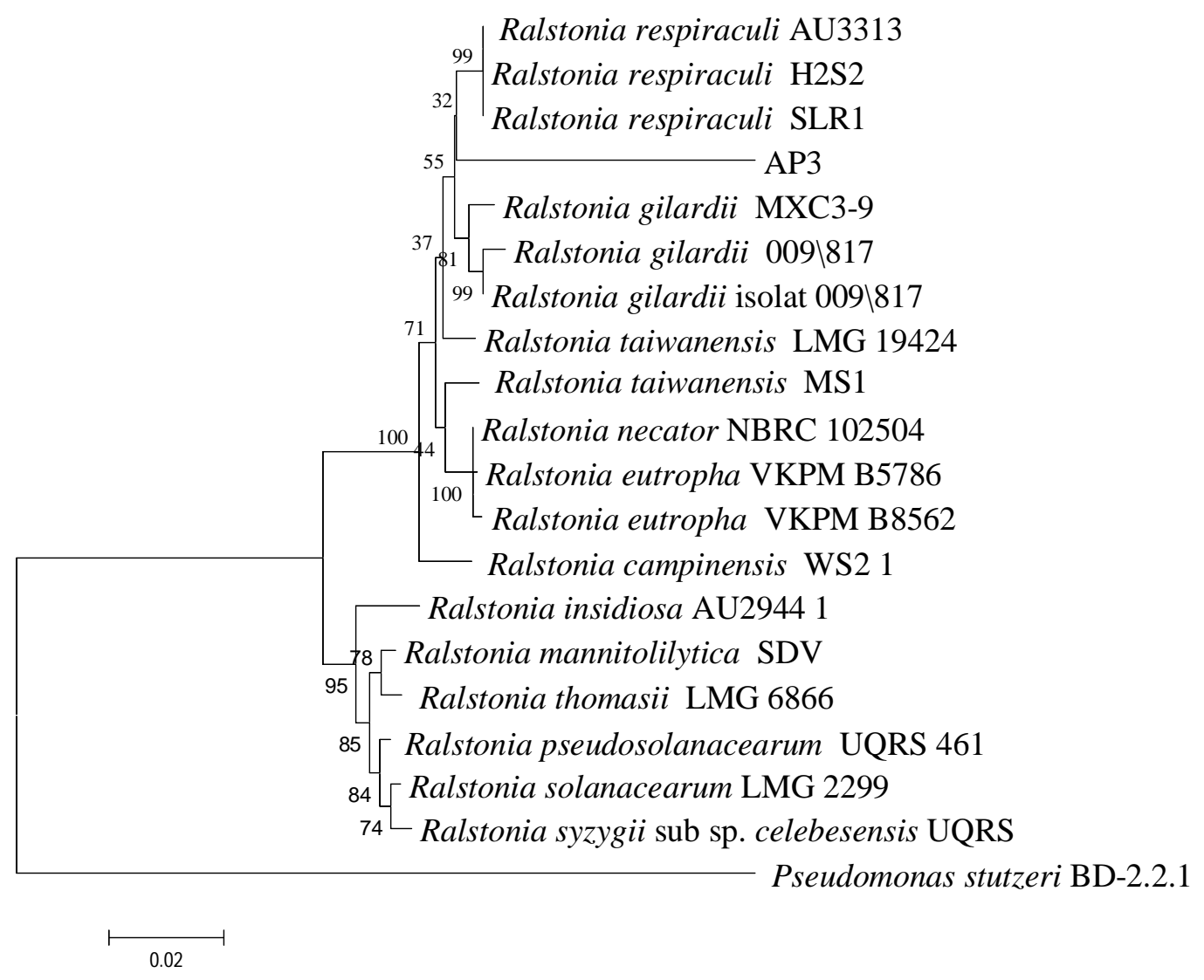

Gambar 7. Pohon filogenetik menunjukkan hubungan kekerabatan antara isolat AP3 berdasarkan sekuen 16S rRNA yang terdapat di GenBank. Rekonstruksi pohon filogenetik menggunakan pendekatan Neighbor-

Joining (NJ) dengan bootstrap 1000x. Sekuen Pseudomonas stutzeri digunakan sebagai outgroup 


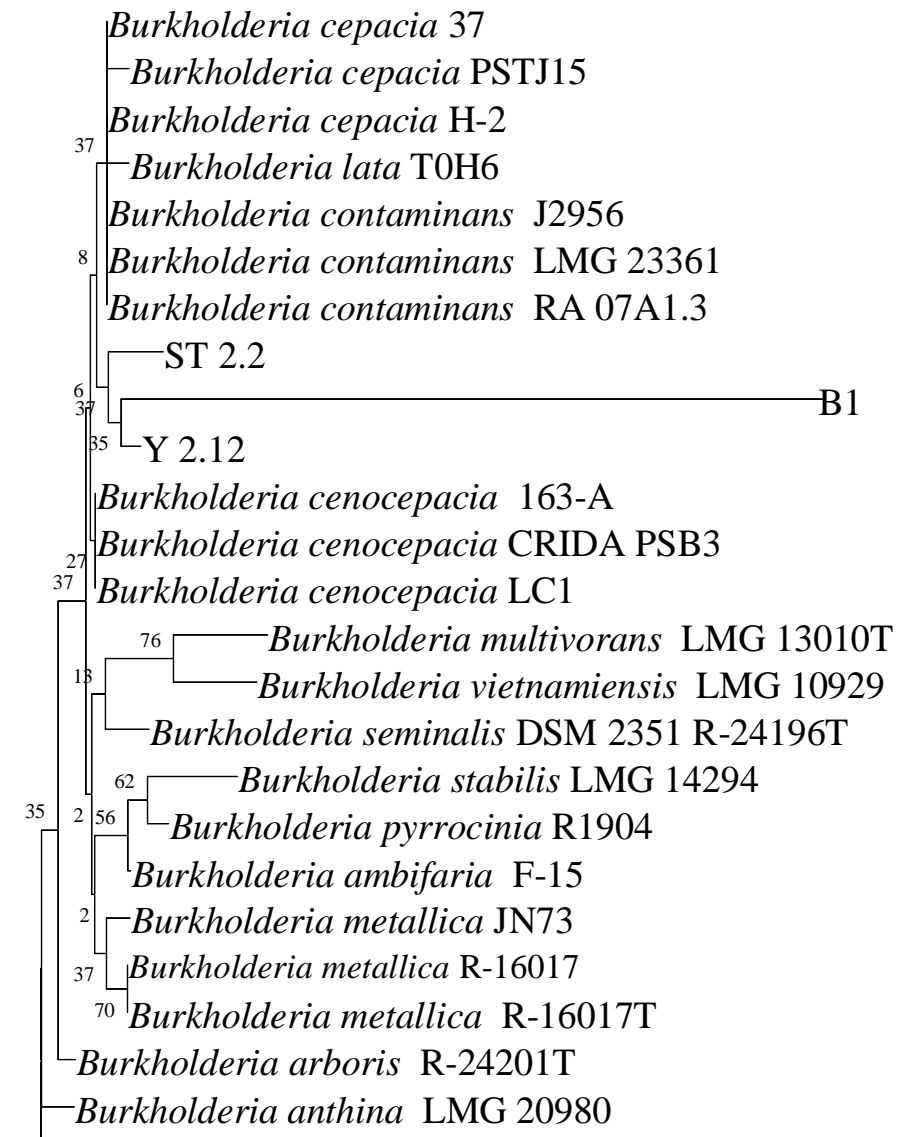

Burkholderia cordobensis LMG 27620T

0.005

Gambar 8. Pohon filogenetik menunjukkan hubungan kekerabatan antara isolat B1, ST 2.2 dan Y 2.12 berdasarkan sekuen 16S rRNA yang terdapat di GenBank. Rekonstruksi pohon filogenetik menggunakan pendekatan Neighbor-Joining (NJ) dengan bootstrap 1000x

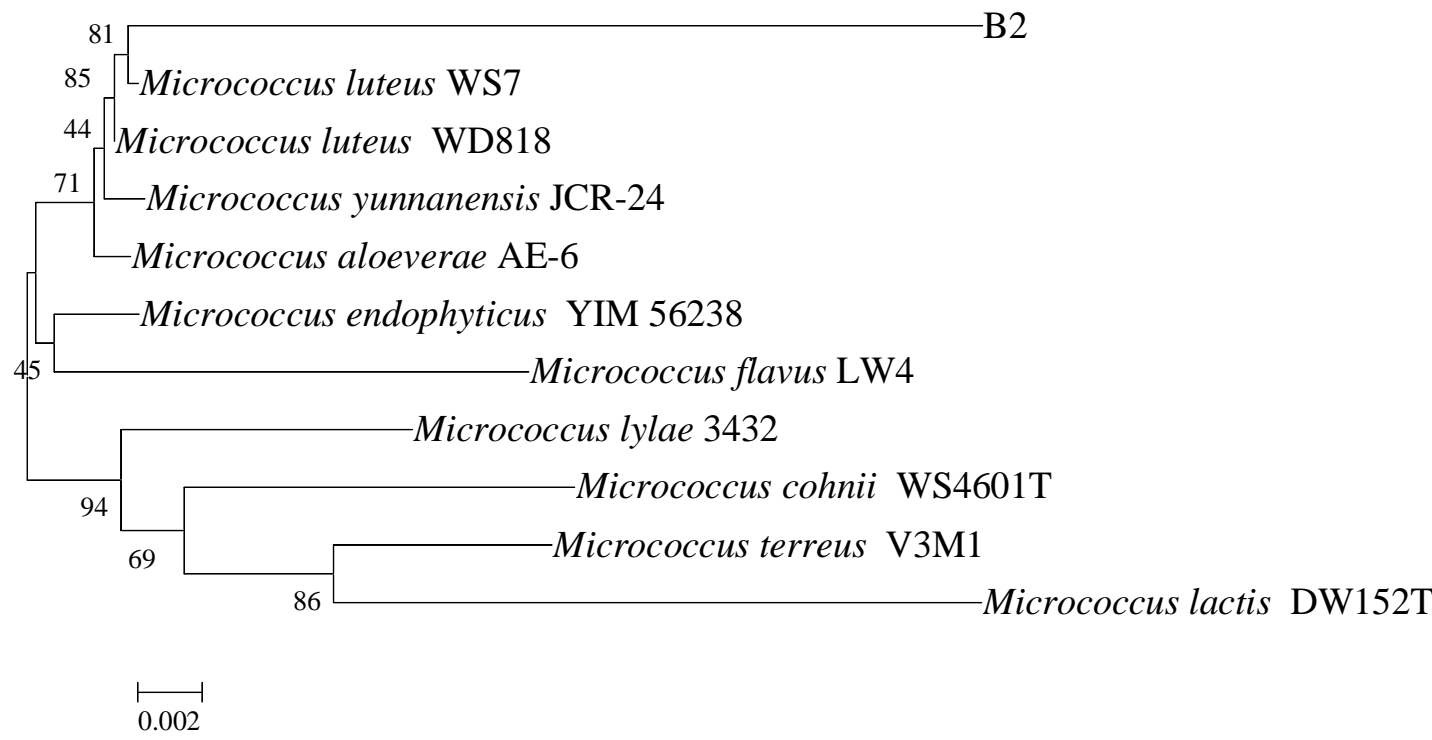

Gambar 9. Pohon filogenetik menunjukkan hubungan kekerabatan antara isolat B2 berdasarkan sekuen 16S rRNA yang terdapat di GenBank. Rekonstruksi pohon filogenetik menggunakan pendekatan Neighbor-Joining (NJ) dengan bootstrap 1000x 
al., 2014), bercak bergaris pada daun tebu dan busuk tunas tebu (Patro, 2006), busuk kayu pohon poplar (Populus nigra) (Tiedemann et al.,1977).

Isolat ST 1.3 sekerabat dengan Escherichia hermannii dengan tingkat kemiripan sebesar $99 \%$ (Gambar 12). Penelitian melaporkan bahwa $E$. hermannii merupakan endofit pada benih jagung (Liu et al., 2013).

Isolat YT 1.17 sekerabat dengan Salmonella bongori dengan tingkat kemiripan sebesar 99\% (Gambar 13). S. enterica merupakan patogen dan ditemukan pada benih Arabidopsis thaliana (Cooley et al., 2003) dan kecambah alfalfa (Rudrappa et al.,
2008). S. bongori ditemukan pada nodul pada batang pohon Conzattia multiflora (Wang et al., 2006).

Isolat YT 1.2 dan Y 2.14 sekerabat dengan Pseudomonas stutzeri dengan tingkat kemiripan 99\% (Gambar 14). P. stutzeri ditemukan pada benih gulma Abutilon theophrasti dan Ipomoea hederacea (Kremer et al., 1987) dan menyebabkan bercak coklat coklat pada jamur tiram (Pleurotus ostreatus) dan jamur kancing (Agaricus bisporus) (Dawoud \& Eweis, 2006).

Pengaruh Isolat Bakteri terhadap Perkecambahan Benih. Hasil sidik ragam pengaruh isolat bakteri terhadap perkecambahan benih akor tertera pada Tabel

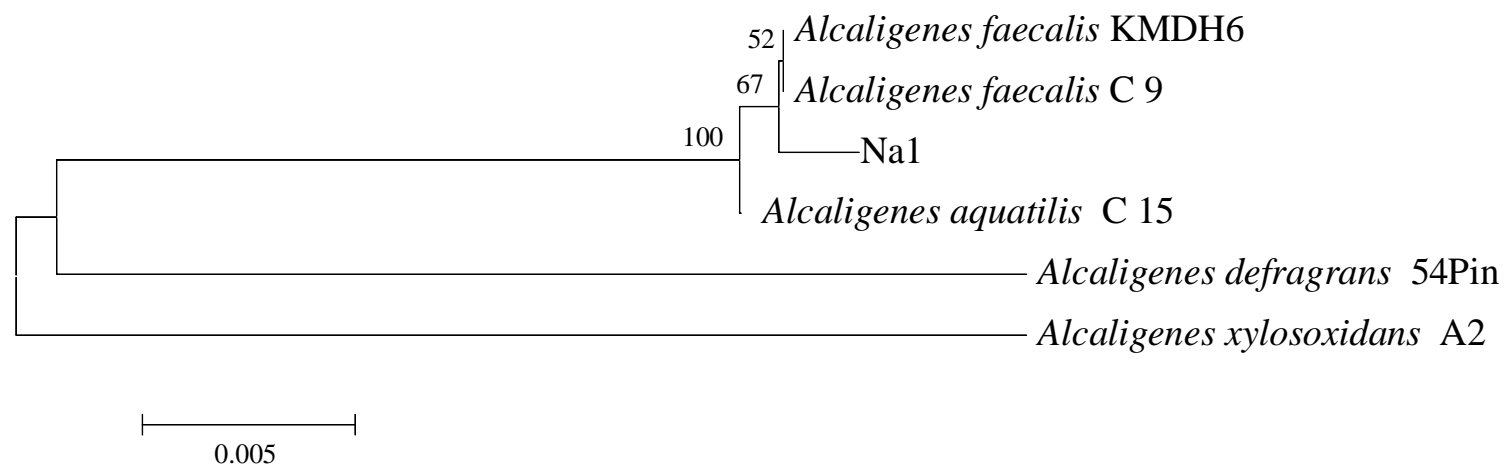

Gambar 10. Pohon filogenetik menunjukkan hubungan kekerabatan antara isolat Na1 berdasarkan sekuen 16S rRNA yang terdapat di GenBank. Rekonstruksi pohon filogenetik menggunakan pendekatan NeighborJoining (NJ) dengan bootstrap 1000x

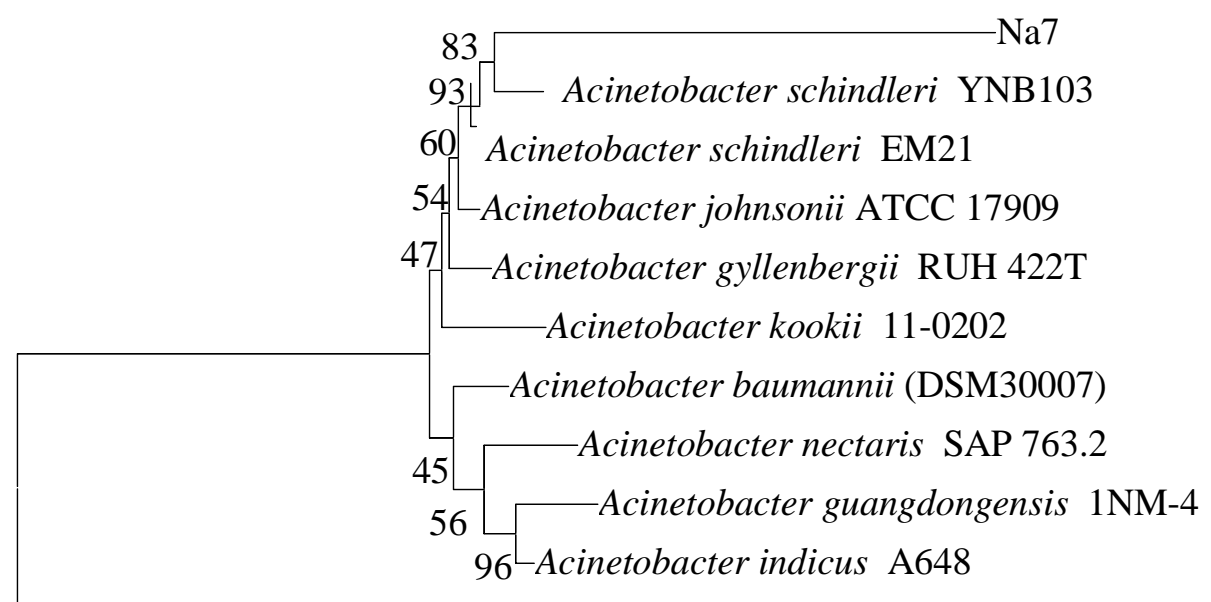

Micrococcus luteus WS7

\subsection{5}

Gambar 11. Pohon filogenetik menunjukkan hubungan kekerabatan antara isolat Na 7 berdasarkan sekuen 16S rRNA yang terdapat di GenBank. Rekonstruksi pohon filogenetik menggunakan pendekatan NeighborJoining (NJ) dengan bootstrap 1000x. Sekuen Micrococcus luteus digunakan sebagai outgroup 
4. Dari Tabel 4 diketahui bahwa isolat bakteri berpengaruh nyata terhadap persentase benih terinfeksi bakteri (berlendir), panjang tunas, panjang akar dan indeks vigor namun tidak berpengaruh nyata terhadap daya berkecambah benih.

Untuk mengetahui perbedaan dari masing-masing perlakuan dilakukan uji beda rata-rata dengan uji Duncan (Tabel 5). Dari Tabel 5 terlihat bahwa pada kontrol, masih terdapat benih yang berlendir (20,5\%), diduga bakteri masih terdapat di permukaan benih walaupun sudah diberi $\mathrm{NaOCl}$ dan air panas. Barampuram et al.,
(2014) melaporkan bahwa sterilisasi benih kapas dengan $\mathrm{H}_{2} \mathrm{O}_{2}$ dapat memperbaiki daya berkecambah dan menurunkan mikroorganisme kontaminan dibanding larutan pemutih $(\mathrm{NaOCl})$. Pencucian permukaan benih tidak dapat menghilangkan S. enterica dan E.coli, hal ini menunjukkan bahwa bakteri berada di tempat yang terlindungi/bagian dalam benih (Cooley et al., 2003). Selain itu berbagai metode sterilisasi permukaan benih pun tidak dapat mematikan bakteri enteric (Beuchat et al., 2001). Namun sterilisasi dengan $\mathrm{NaOCl}$ dapat meningkatkan daya berkecambah sebesar $6 \%$ dan

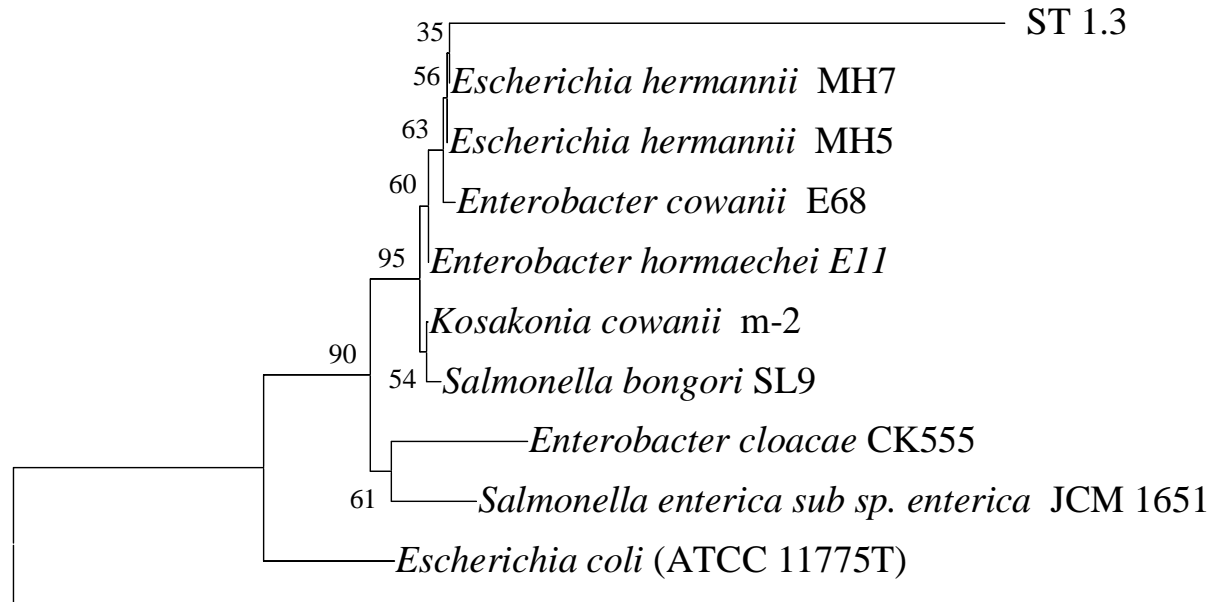

Pseudomonas stutzeri BD-2.2.1

$$
0.02
$$

Gambar 12. Pohon filogenetik menunjukkan hubungan kekerabatan antara isolat ST 1.3 berdasarkan sekuen 16S rRNA yang terdapat di GenBank. Rekonstruksi pohon filogenetik menggunakan pendekatan NeighborJoining (NJ) dengan bootstrap 1000x. Sekuen Pseudomonas stutzeri digunakan sebagai outgroup

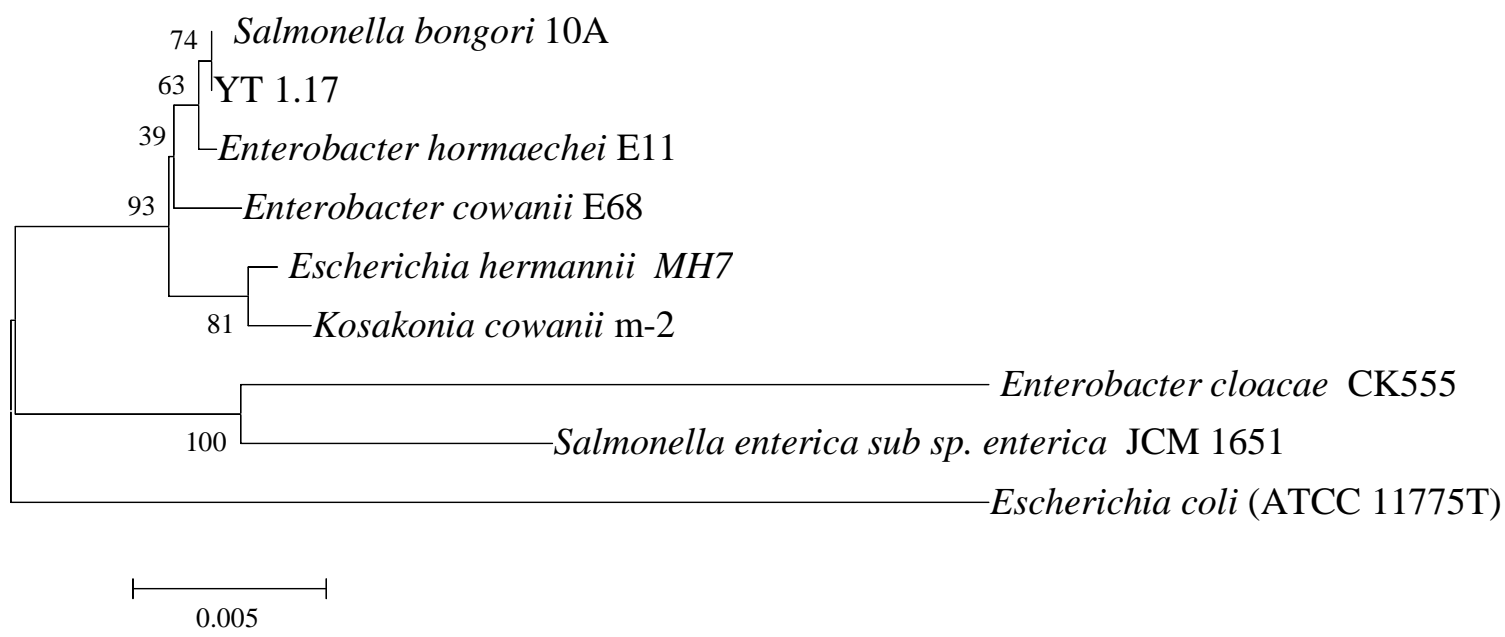

Gambar 13. Pohon filogenetik menunjukkan hubungan kekerabatan antara isolat isolat YT 1.17 berdasarkan sekuen 16S rRNA yang terdapat di GenBank. Rekonstruksi pohon filogenetik menggunakan pendekatan Neighbor-Joining (NJ) dengan bootstrap 1000x 
menurunkan persentase benih berlendir sebesar 21,5\% dibanding perlakuan pendahuluan dengan air panas (KU).

Bakteri tahan terhadap disinfektan dan suhu tinggi karena adanya pertahanan sel biofilm. Terbentuknya beberapa lapis biofilm (multilayer) menyebabkan senyawa klorin tidak bisa menembus bagian dalam. Semakin banyak matriks ekstraseluler yang dikeluarkan semakin besar kemampuan menghalangi masuknya klorin. Selain itu senyawa ekstraseluler sebagian besar merupakan senyawa organik dapat menghambat mekanisme kerja klorin. Biofilm Salmonella sp. dan $E$. coli sulit dihilangkan walaupun dengan suhu $100{ }^{\circ} \mathrm{C}$ karena EPS dapat melindungi sel sehingga tidak semua bakteri dapat dimatikan. Suhu panas merusak EPS dan sebagian besar bakteri yang dekat dengan permukaan (Silitonga et al., 2012).

Secara umum daya berkecambah benih yang diinokulasi bakteri lebih rendah dibanding kontrol sedangkan jumlah benih berlendir lebih tinggi dibanding kontrol. Daya berkecambah kontrol lebih besar dibanding daya berkecambah pada perlakuan panas dan dibiarkan dingin selama 24 jam (KU). Daya berkecambah kontrol sebesar 47,5\%. Suita (2013) melaporkan bahwa daya berkecambah benih akor asal Riau sebesar 41,33- 62 $\%$. Semua parameter yang diamati pada benih yang diinokulasi E. hermannii dan Paenochrobactrum sp. relatif sama dengan pada kontrol.

Burkholderia cepacia complex, A. faecalis, Acinetobater sp., P. stutzeri, S. bongori dan Ralstonia

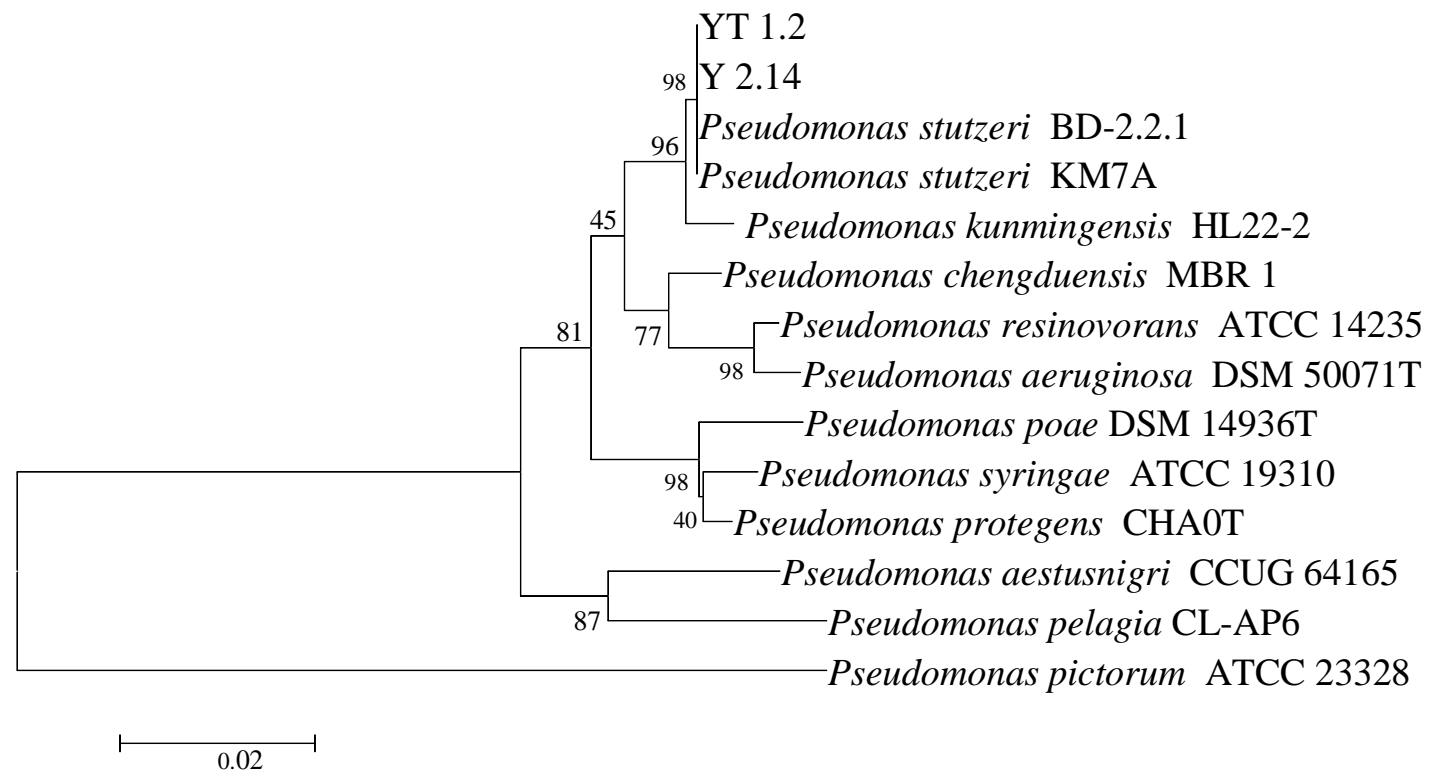

Gambar 14. Pohon filogenetik menunjukkan hubungan kekerabatan antara isolat isolat YT 1.2 dan Y 2.14 berdasarkan sekuen 16S rRNA yang terdapat di GenBank. Rekonstruksi pohon filogenetik menggunakan pendekatan Neighbor-Joining (NJ) dengan bootstrap 1000x

Tabel 4. Analisis sidik ragam pengaruh pengaruh isolat bakteri terhadap perkecambahan benih akor

\begin{tabular}{lc}
\hline Peubah & F hitung \\
\hline Daya berkecambah & 1,054 \\
Permukaan berlendir & 1,520 \\
Hampa berlendir & $6,516^{* *}$ \\
Total lendir & $2,451^{*}$ \\
Panjang tunas & $2,11^{*}$ \\
Panjang akar & $13,89^{* *}$ \\
Indeks vigor & $2,585^{*}$ \\
\hline
\end{tabular}

$*$ = berpengaruh nyata pada tingkat kepercayaan $95 \%$ 


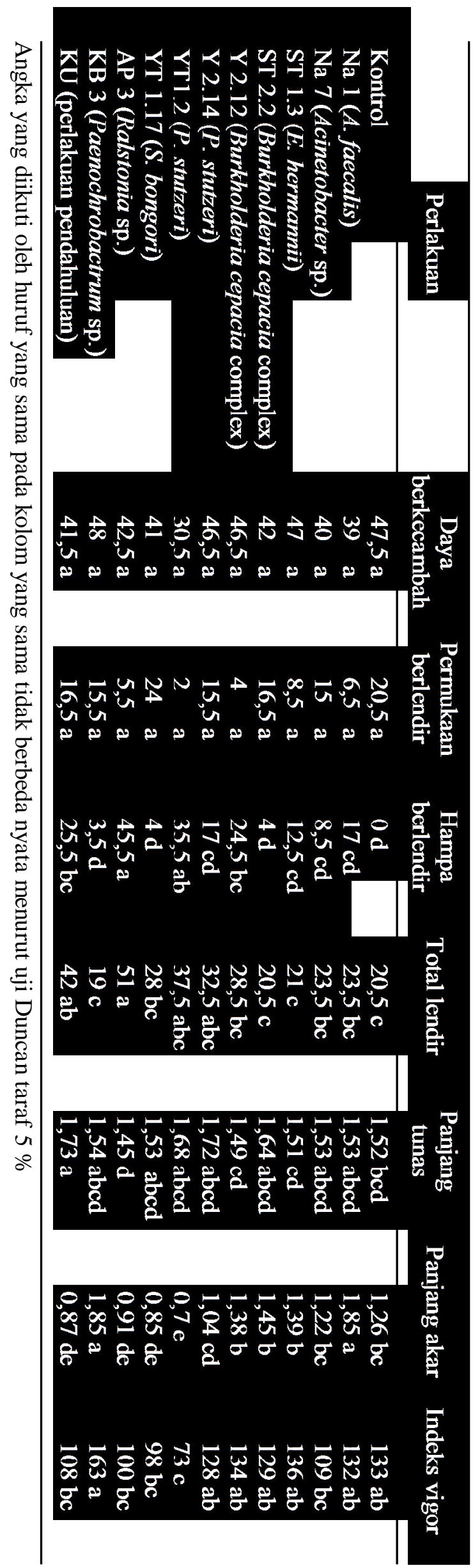

sp. dapat menurunkan daya berkecambah dan meningkatkan persentase benih berlendir. Bakteri tersebut dilaporkan dapat sebagai patogen tanaman seperti Burkholderia cepacia complex (Ibrahim et al., 2012), Acinetobacter (Jackson, 2009 dalam Khan, 2014), Ralstonia (Coenye et al., 1999), P. stutzeri (Dawoud \& Eweis, 2006) dan Salmonella (Kirzinger et al., 2011).

Panjang akar pada perlakuan Paenochrobactrum sp. lebih tinggi dari kontrol sedangkan perlakuan $P$. stutzeri, S. bongori dan Ralstonia sp. menghasilkan panjang akar yang lebih rendah dan berbeda nyata dengan kontrol. Dengan demikian indeks vigor benih yang diinokulasi Paenochrobactrum sp. lebih tinggi dibanding kontrol sedangkan indeks vigor benih yang diinokulasi $P$. stutzeri, $S$. bongori dan Ralstonia sp. lebih rendah dibanding kontrol.

Panjang tunas pada perlakuan inokulasi $P$. stutzeri lebih tinggi sedangkan panjang akar lebih pendek dibanding kontrol. Sejalan dengan penelitian Raheem \& Ali (2015) yang melaporkan bahwa panjang tunas gandum yang diinokulasi $P$. stutzeri lebih besar dibanding kontrol. Azmat (2014) melaporkan bahwa inokulasi $P$. stutzeri pada benih kacang hijau menyebabkan penurunan panjang akar.

A. faecalis dapat menurunkan daya berkecambah dan meningkatkan panjang akar dibanding kontrol. Alcaligenes sp. menghasilkan auksin yang berfungsi dalam pertumbuhan akar tanaman (Mihalache, 2015). Penelitian lain (Kremer, 1990) melaporkan bahwa A. faecalis dapat menghambat pertumbuhan bibit beberapa jenis gulma. Bakteri menghasilkan toksin yang dapat menurunkan viabilitas benih dan vigor bibit.

Auksin mempunyai peranan dalam patogenesitas bakteri. Auksin yang dihasilkan dapat menginduksi tanaman untuk menghasilkan auksin sehingga konsentrasi auksin tinggi. Konsentrasi auksin tinggi dapat meningkatkan virulensi patogen (Fu et al., 2011 dalam Duca et al., 2014). Selain itu konsentrasi auksin yang tinggi merupakan salah satu mekanisme patogen untuk mengkolonisasi inang (Chen et al., 2007 dalam Duca et al., 2014).

Panjang akar pada perlakuan (Burkholderia cepacia complex) lebih besar dibanding kontrol. Burkholderia sp. menghasilkan hormon giberelin dan enzim ACC deaminase yang berfungsi untuk mengatur pertumbuhan dan perkembangan akar (Mihalache, 2015). Hormon giberelin berperan juga dalam patogenesis (Baca \& Elmerich, 2007). Menurut Levy (2007), B. vietnamiensis dapat menurunan pesentase perkecambahan Trifolium subterraneum dengan 
populasi $1 \times 10^{6}$ sehingga $B$. vietnamiensis bv. trifolii merupakan patogen tanaman dan menurunkan perkecambahan Acacia colei pada populasi $1 \times 10^{8}$ namun bakteri ini dapat meningkatkan perkecambahan A. colei pada populasi $1 \times 10^{6}$ sehingga bakteri ini menguntungkan atau merugikan tergantung pada jenis benih (genotipe tanaman) dan kepadatan populasi bakteri.

Escherichia sp. dapat menghasilkan sitokinin (Mihalache, 2015). Sitokinin berperan dalam pertumbuhan tanaman dan juga patogenesis (Baca \& Elmerich, 2007). Rata-rata panjang akar benih akor yang diinokulasi bakteri ini lebih tinggi dibanding kontrol. $E$. hermannii dapat menyebabkan fitotoksik lemah (Zhao, 2009).

Bakteri menimbulkan penyakit salah satunya karena mempunyai faktor patogenesitas dan tingkat patogenesitas dipengaruhi oleh faktor virulensi (Joko et al., 2014). Beberapa faktor penentu patogenesitas bakteri patogen tanaman antara lain sistem sekresi tipe I-VI (Rakhashiya et al., 2016), eksopolisakarisa (EPS) dan lipopolisakarida (LPS) (Arwiyanto, 2014). T3SS merupakan mekanisme penting dalam patogenesitas bakteri Gram negatif patogen tanaman (Rakhashiya et al., 2016). Keberadaan salah satu atau beberapa faktor penentu patogenesitas dapat menyebabkan bakteri bersifat patogen atau deleterious terhadap inang. Beberapa bakteri endofit dilaporkan mengandung gen faktor virulensi seperti Salmonella enterica (Barak, 2005).

\section{SIMPULAN}

Bakteri terbawa benih akor (A. auriculiformis) antara lain Paenochrobactrum sp., Ralstonia sp., Burkholderia cepacia complex, Pseudomonas stutzeri, Acinetobacter sp., Alcaligenes faecalis, Salmonella bongori, Escherichia hermannii sedangkan patogen penyebab bercak pada daun bibit akor adalah Micrococcus luteus dan Burkholderia cepacia complex. Burkholderia cepacia complex A. faecalis, Acinetobater sp., P. stutzeri, S. bongori dan Ralstonia sp. dapat menurunkan daya berkecambah dan meningkatkan persentase benih berlendir sehingga bakteri tersebut diduga merupakan patogen pada benih akor. Ralstonia sp. meningkatkan persentase benih berlendir dan menurunkan panjang tunas dan panjang akar. P. stutzeri dan $S$. bongori menghambat pertumbuhan akar. Paenochrobactrum sp. dan $E$. hermannii diduga merupakan patogen dengan virulensi lemah karena daya berkecambah, persentase infeksi benih terinfeksi dan index vigor benih yang diinokulasi E. hermannii dan Paenochrobactrum sp. relatif sama dengan pada kontrol.

\section{SANWACANA}

Penulis mengucapkan terima kasih kepada Pusat Diklat Kehutanan, Kementerian Lingkungan Hidup dan Kehutanan yang telah membantu dana penelitian ini serta Ibu Ir. Woro Darmini, Pak Andri dan Pak Maryono yang telah membantu terlaksananya penelitian ini.

\section{DAFTAR PUSTAKA}

Arwiyanto T. 2015. Ralstonia solanacearum: Biologi, Penyakit yang Ditimbulkan dan Pengelolaannya. Gadjah Mada University Press.

Ausubel FM, Brent R, Kingston RE, Moore DD, Seidman JG, \& Smith JA. 2003. Current Protocols in Molecular Biology. John Willyey \& Sons Inc.

Avise JC. 1994. Molecular Markers, Natural History and Evolution. NewYork: Chapman \& Hall.

Azmat R. 2014. The impact of siderophore secretion by Pseudomonas stutzeri to chelating $\mathrm{Cu}$ metal in solution culture. Pak. J. Bot. 46(1) : 383-387.

Baca BE \& Elmerich C. 2007. Microbial production of plant hormones. In: Elmerich C \& Newton WE (eds.). Associative and Endophytic Nitrogenfixing Bacteria and Cyanobacterial Associations. pp. 113-143. Springer, The Netherlands.

Balestra GM, Agostini R, Bellincontro A, Mencarelli F, \& Varvaro L. 2005. Bacterial populations related to gerbera (Gerbera jamesonii L.) stem break. Phytopathol. Mediterr. 44: 291-299.

Barak JD, Gorski L, Naraghi-Arani P, \& Charkowski AO. 2005. Salmonella enterica virulence genes are required for bacterial attachment to plant tissue. Appl. Environ. Microbiol. 71(10): 5685-5691.

Barampuram S, Allen G, \& Krasnyansi KS. 2014. Effect of various sterilization procedures on the in vitro germination of cotton seeds. Research Note. Plant Cell Tiss. Org. 118(1): 179-185.

Berlian I. 2012. Analisis Patogenesitas dan Karakterisasi Keragaman Genetik Banana Blood Diseases Bacterium (BBDB). [Tesis]. Universitas Gadjah Mada, Yogyakarta. 
Beuchat LR, Ward TE, \& Pettigrew CA. 2001. Comparison of chlorine and a prototype produce wash product for effectiveness in killing Salmonella and Escherichia coli $\mathrm{O} 157: \mathrm{H} 7$ on alfalfa seeds. J. Food Prot. 64(2): 152-158.

Bolkan HA, Waters CM, \& Fatmi M. 1997. Clavibacter michiganenesis sub sp. michiganensis. Working Sheet 67 In: ISTA Handbook on Seed Health Testing. Zurich, Switzerland: International Seed Testing Association.

Coenye T, Falsen E, Vancanneyt M, Hoste B, Govan JRW, Kersters K, \& Vandamme P. 1999. Classification of Alcaligenes faecalis-like isolates from the environment and human clinical samples as Ralstonia gilardii sp. nov. Int. J. of Syst. Bacteriol. 49: 405-413.

Coenye T, Vandamme P, Govan JRW, \& LiPuma JJ. 2001. Taxonomy and identification of the Burkholderia cepacia complex. J. Clin. Microbiol. 39(10): 3427-3436.

Compant S, Reiter B, Sessitsch A, Nowak J, Clement C, \& Barka EA. 2005. Endophytic colonization of Vitis vinifera L. by plant growth-promoting bacterium Burkholderia sp. strain PsJN. Appl. Environ. Microbiol. 71(4): 1685-1693.

Cooley MB, Miller WG, \& Mandrell RE. 2003. Colonization of Arabidopsis thaliana with Salmonella enterica and enterohemorrhagic Escherichia coli $\mathrm{O} 157: \mathrm{H} 7$ and competition by Enterobacter asburiae. Appl. Environ. Microbiol. 69(8): 4915-4926.

Dawoud MEA \& Eweis M. 2006. Phytochemical control of edible mushrooms pathogenic bacteria. J. Food, Agric. Environ. 4(1): 321-324.

Duca D, Lorv J, Patten CL, Rose D, \& Glick BR. 2014. Indole-3-acetic acid in plant-microbe interactions. Antonie van Leeuwenhoek 106(1): 85-125.

Fanani AK, Abadi AL, \&Aini LQ. 2015. Eksplorasi bakteri patogen pada beberapa spesies tanaman kantong semar (Nepenthes sp.). Jurnal HPT 3(3) :104-110.

Castro-Gonzalez R, Martinez-Aguilar L \& RamirezTrujillo A, Estrada-de los Santos P, \& CaballeroMellado J. 2011. High diversity of culturable Burkholderia species associated with sugarcane. Plant Soil 345(1): 155-169.
Gosling P. 2007. Raising Trees and Shrubs from Seed. Practice Guide. Forestry Commision. Edinburgh.

Hadianto W, Hakim L, \& Bakhtiar. 2015. Ketahanan beberapa genotipe padi terhadap penyakit hawar daun bakteri (Xanthomonas oryzae pv. oryzae). Jurnal Hama dan Penyakit Tumbuhan Tropika 15(2): 152-163.

Haishui Z \& Zengjiang Y. 1993. Acacias for rural, industrial, and environmental development in Southern China. In: Awang K \& Taylor DA (eds.). Acacias for Rural, Industrial, and Environmental Development. pp. 15-20 .The Second Meeting of the Consultative Group for Research and Development of Acacias (COGREDA), Thailand, February, 15-18, 1993.

Hendrati RL, Nurrohmah SH, Susilawati S, \& Budi S. 2014. Budidaya Acacia auriculiformis untuk Kayu Energi. IPB Press.

Iakovleva LM, Makhinia LV, Shcherbina TN, \& Ogorodnik LE. 2013. Micrococcus sp. the pathogen of leaf necrosis of horse-chestnuts (Aesculus L.) in Kiev. Mikrobiol. Z. 75(3): 6267.

Ibrahim M, Tang Q, Shi Y, Almoneafy A, Fang Y, Xu L, Li W, Li B, \& Xie GL. 2012. Diversity of potential pathogenicity and biofilm formation among Burkholderia cepacia complex water, clinical and agricultural isolates in China. World $J$. Microb. Biot. 28(5): 2113-2123.

Islam SS, Islam MS, Hossain Md. AT, \& Alan Z. 2013. Optimal rotation interval of akashmoni (Acacia auriculiformis) plantations in Bangladesh. Kasetsart J. Soc. Sci. 34: 181-190.

Joker. 2001. Acacia auriculiformis Cunn. ex Benth. Informasi Singkat Benih. Direktorat Perbenihan Tanaman Hutan.

Joko T, Kusumandari N, \& Hartono S. 2011. Optimasi metode PCR untuk deteksi Pectobacterium carotovorum, penyebab penyakit busuk lunak anggrek. Jurnal Perlindungan Tanaman Indonesia 17(2): 54-59.

Joko T, Subandi A, Kusumandari N, Wibowo A, \& Priyatmojo A. 2014. Activities of plant cell walldegrading enzymes by bacterial soft rot of orchid. Arch. Phytopathol. Plant Prot. 47(10): 12391250. 
Kaur N, Sharma S, Sood A, \& Kumar V. 2009. Incidence and interaction of seed borne micro flora of Cassia fistula in the Himalayan Region. Cameroon J. Exp. Biol. 5(1) : 21-24.

Khan IA, Khan A, Asif H, Jiskani MM, Muhlbach HP, \& Azim MK. 2014. Isolation and 16s rDNA sequence analysis of bacteria from dieback affected mango orchards in Southern Pakistan. Pakistan J. Bot. 46(4): 1431-1435.

Kirzinger MWB, Nadarasah G, \& Stavrinides J. 2011. Insights into cross-kingdom plant pathogenic bacteria. Genes 2(4): 980-997.

Kremer RJ. 1987. Identity and properties of bacteria inhabiting seeds of selected broadleaf weed species. Microb. Ecol. 14(1): 29-37.

Kremer RJ, Begonia MFT, Stanley L, \& Lanham ET. 1990. Characterization of rhizobacteria associated with weed seedlings. Appl. Environ. Microbiol. 56(6): 1649-1655.

Levy A. 2007. Modelling Rhizosphere Interactions of Burkholderia Species. [Thesis]. Microbiology and Immunology School of Biomedical and Chemical Sciences. The University of Western Australia.

Liu Z, Zuo S, Zou Y, Wang J, \& Song W. 2013. Investigation on diversity and population succession dynamics of endophytic bacteria from seeds of maize (Zea mays L., Nongda108) at different growth stages. Ann. Microbiol. 63(1): 71-79.

Mahenthiralingam E., Bischof J, Byrne SK, Radomski C, Davies JE, Av-Gay Y, \& Vandamme P. 2000. DNA-based diagnostic approaches for identification of Burkholderia cepacia complex, Burkholderia vietnamiensis, Burkholderia multivorans, Burkholderia stabilis, and Burkholderia cepacia Genomovars I and III. J. Clin. Microbiol. 38(9): 3165-3173.

Marchesi JR, Sato T, Weightman AJ, Martin TA, Fry JC, Hiom SJ, Dymock D, \& Wade WG. 1998. Design and evaluation of useful bacterium-specific PCR primers that amplify genes coding for bacterial 16S rRNA. Appl. Environ. Microb. 64(2): 795-799.

Mihalache G, Zamfirache MM, \& Stefan M. 2015. Root associated bacteria - friends or enemies?. Memoirs of the Scientific Sections of the Romanian Academy Tome XXXVIII: 28-54.
Ofek M, Hadar Y, \& Minz D. 2011. Colonization of cucumber seeds by bacteria during germination. Environ. Microbiol. 13(10): 2794-2807.

Patro TSSK, Rao GVN, \& Gopalakrishnan J. 2006. Association of Acinetobacter baumannii with a top rot phase of sugarcane redstripe disease in India. Indian Phytopathology 59(4): 501-502.

Raheem A \& Ali B. 2015. Halotolerant rhizobacteria: beneficial plant metabolites and growth enhancement of Triticum aestivum L. in saltamended soils. Arch. Agronom. Soil Sci. 61(12): 1691-1705.

Rakhashiya PM, Patel PP, \& Thaker VS. 2015. Whole genome sequences and annotation of Micrococcus luteus SUBG006, a novel phytopathogen of mango. Genomics Data 6: 10 15.

Rakhashiya PM, Patel PP, Sheth BP, Tank JG, \& Thaker VS. 2016. Detection of virulence and pathogenicity genes in selected phytopathovars. Arch. of Phytopathology Plant Protect. 49(1 4): 64-73.

Rivas R, Fraile PG, Mateos PF, Martinez EM, \& Velazquez E. 2007. Characterization of xylanolytic bacteria present in the bract phyllosphere of the date palm Phoenix dactylifeca. Lett. Appl. Microbiol. 44(2): 181187.

Rudrappa T, Biedrzycki ML, \& Bais HP. 2008. Causes and consequences of plant-associated biofilms. FEMS Microbiol. Ecol. 64(2): 153 - 166.

Sands DC. 1990. Physiological criteria: determinative tests. In: Klement Z, Rudolph K, \& Sands DC (eds.). Methods in Phytobacteriology. pp. 133143. Akademiai Kiado, Budapest.

Schaad NW, Jones JB, \& Chun W. 2001. Laboratory Guide for Identification of Plant Pathogenic Bacteria. Third Edition. APS Press.

Silitonga YW, Jamilah I, \& Suryanto D. 2012. Pengendalian sel biofilm bakteri patogen oportunistik dengan panas dan klorin. Saintia Biologi 1(1): 46-51.

Suita E. 2013. Pengaruh sortasi benih terhadap viabilitas dan pertumbuhan bibit akor (Acacia auriculiformis). Jurnal Perbenihan Tanaman Hutan 1(2): 83-91. 
Tamura K, Stecher G, Peterson D, Filipski A, \& Kumar S. 2013. MEGA6: molecular evolutionary genetics analysis version 6.0. Mol. Biol. Evol. 30(12): 2725-2729.

Tiedemann G, Bauch J, \& Bock E. 1977. Occurrence and significance of bacteria in living trees of Populus nigra L. Forest Pathology 7(6): 364374.

Turnbull JW, Midgley SJ, \& Cossalter C. 1998. Tropical acacias planted in Asia : an overview. In: Tumbull JW, Crompton HR, \& Pinyopusarerk K (eds.). Recent Developments in Acacia Planting. pp. 14-28. Australian Centre for International Agricultural Research, Hanoi, Vietnam, October, 27-30, 1997.

Ukoima HN, Wemedo SA, \& Ekpirikpo AO. 2009. Survey of bacterial pathogens on leaves and seeds of red mangrove (Rhizophora mangle). African J. Environ. Sci. Technol. 3(5): 116-119.

Umesha S. 2006. Occurrence of bacterial canker in tomato fields of Karnataka and effect of biological seed treatment on disease incidence. Crop Prot. 25(4): 375-381.

Vanlaere E, Baldwin A, Gevers D, Henry D, De Brandt E, LiPuma JJ, Mahenthiralingam E, Speert DP, Dowson C, \& Vandamme P. 2009. Taxon K, a complex within the Burkhlolderia cepacia complex, comprises at least two novel species, Burkholderia contaminans sp. nov. and Burkholderia lata sp. nov. Int. J. Systematic and Evolutionary. Microbiol. 59: 102-111.
Wang ET, Tan ZY, Guo XW, Duran RR, Boll G, \& Romero EM. 2006. Diverse endophytic bacteria isolated from a leguminous tree Conzattia multiflora grown in Mexico. Arch. Microbiol. 186(4): 251-259.

Xie L, Ju Y, \& Zhao B. 2004. Dynamics of populations of nematode and bacteria in the process of pine wilt disease. Scientia Silvae Sinicae 40(4): 124129.

You L, Wei Q, Gua H, \& Zhang Y. 2013. Phylogenetic diversity of cultivable endophytic bacteria isolated from Litsea cubeba. J. Northwest A\& F University - Natural Science Edition 4(4): 210216.

Yun SC \& Kim YH. 2003. Pathogenic bacteria causing rot in commercial soybean sprout cultivation. Korean J. Crop Sci. 48(2): 113-119.

Zhao BG, Lin F, Guo D, Li R, Li S, Kulinich O, \& Ryss A. 2009. Pathogenic roles of the bacteria carried by Bursaphelenchus mucronatus. J. Nematol. 41(1): 11-16. 